Syntax Idea: p-ISSN: 2684-6853 e-ISSN: 2684-883X

Vol. 3, No. 3, Maret 2021

\title{
EKSPLORASI PELAKSANAAN EVALUASI PEMBELAJARAN DARING MAHASISWA PPKn PADA ERA NEW NORMAL
}

\author{
Marlyen Sharly Sapulette
}

Universitas Pattimura Ambon, Indonesia

Email: msharly271@gmail.com

\section{Abstract}

This research was conducted at the Faculty of Teacher Training and Education (FKIP), Pancasila and Citizenship Education (PPKn) Study Program, Pattimura University. During the new normal period (Pandemic Covid-19), Pattimura University implemented an online learning process in all Faculties, at the Teaching and Education Faculty, especially the PPKn Study Program, online learning became a separate obstacle for PPKn Lecturers in providing learning information due to college students inactive and inadequate focus during the learning process. In an effort to ensure that the online learning process can continue to be carried out well, this research was conducted. This study aims to implement an effective online learning evaluation to determine the level of understanding of PPKn college students in receiving course material. In this research, the online learning evaluation system implemented includes: (a) learning journals as college students evaluation materials in reviewing the material presented, (b) case studies as a way of thinking of college students in expressing opinions related to issues that occur in society, (c) film review articles as a form of creativity, knowledge to hone college students writing skills, (d) teaching simulation as a method to develop college student teaching skills as prospective educators. The research method used is descriptive qualitative to describe the alternative solution to the problem of learning evaluation. The results showed that the implementation of online learning evaluation can make it easier for lecturers to assess the extent of the success of the implementation of online learning in the PPKn Study Program, especially during the Pandemic Covid-19.

Keywords: ppkn study program; online learning; learning evaluation; college students

\begin{abstract}
Abstrak
Penelitian ini dilakukan pada Fakultas Keguruan dan Ilmu Pendidikan (FKIP) Program Studi Pendikan Pancasila dan Kewarganegaraan (PPKn). Universitas Pattimura. Selama era new normal (Pandemic Covid-19) Universitas Pattimura menerapkan proses pembelajaran daring di semua Fakultas, pada Fakultas Keguruan dan Ilmu Pendidikan terutama Program Studi PPKn pembelajaran daring menjadi hambatan tersendiri bagi Dosen PPKn dalam memberikan informasi pembelajaran karena adanya mahasiswa yang tidak aktif dan kurang fokus selama proses pembelajaran. Sebagai upaya agar proses pembelajaran daring dapat tetap terlaksana dengan baik, maka penelitian ini dilakukan. Penelitian ini bertujuan untuk menerapkan evaluasi pembelajaran daring yang efektif untuk mengetahui tingkat pemahaman mahasiswa PPKn dalam menerima
\end{abstract}


materi kuliah. Pada penelitian ini sistem evaluasi pembelajaran daring yang dilaksanakan, meliputi: (a) jurnal pembelajaran sebagai bahan evaluasi mahasiswa dalam meninjau kembali materi yang disampaikan, (b) studi kasus sebagai cara berpikir mahasiswa dalam menyampaikan pendapat terkait isu yang terjadi di masyarakat (c) artikel review film sebagai bentuk kreatifitas, pengetahuan untuk mengasah kemampuan menulis mahasiswa, (d) simulasi mengajar sebagai metode untuk mengembangkan ketrampilan mengajar mahasiswa sebagai calon pendidik. Metode Penelitian yang digunakan adalah kualitatif deskriptif untuk menggambarkan alternatif pemecahan masalah evaluasi pembelajaran. Hasil penelitian menunjukkan dengan diterapkannya evaluasi pembelajaran daring dapat memudahkan dosen untuk menilai sejauhmana keberhasilan pelaksanaan pembelajaran daring di Prodi PPKn khusunya selama Pandemic Covid-19.

Kata Kunci: prodi PPKn; pembelajaran daring; evaluasi pembelajaran; mahasiswa

Coresponden Author

Email: msharly271@gmail.com Artikel dengan akses terbuka dibawah lisensi

\section{Pendahuluan}

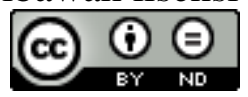

Menyebarnya Pandemic Covid-19 di Indonesia pada pertengahan bulan Maret 2020, membuat Pemerintah Indonesia dalam hal ini Kementeriaan Pendidikan dan Kebudayaan mengeluarkan kebijakan yaitu Surat Edaran (SE) Menteri Pendidikan dan Kebudayaan (Mendikbud) Nomor 36962/MPK.A/HK/2020 tertanggal 17 Maret 2020 tentang Pembelajaran secara Daring dan Bekerja dari Rumah dalam rangka Pencegahan Penyebaran Corona Virus Disease (COVID-19) (PAUD Kemdikbud, 2020).

Kebijakan yang dikeluarkan cukup mempengaruhi sistem pendidikan yang ada di Indonesia, dikarenakan kegiatan pembelajaran yang pada umumnya dilaksanakan melalui proses tatap muka secara berdekatan (konvensional) beralih menjadi proses tatap muka secara berjauhan (online) dengan menggunakan berbagai fitur video conference maupun aplikasi perangkat lunak lainnya dalam memberikan tugas atau menyampaikan materi.

Dalam bukunya yang berjudul "Pengantar Pendidikan" (Mudyahardjo Redja, 2013) mengungkapkan bahwa melalui Pendidikan setiap individu dapat mengembangkan pengetahuan selama hidupnya melalui interaksi sosial antara keluarga maupun masyarakat, yang dapat mempengaruhi perkembangan dan pola pikirnya.

Dari pernyataan diatas, maka terpampang jelas bahwa pendidikan sangatlah penting bagi setiap individu, hal inilah mengapa pendidikan harus tetap dilaksanakan dalam keadaan apapun termasuk di saat pandemic sekarang ini terutama pelaksanaan pembelajaran bagi siswa maupun mahasiswa pada setiap lembaga pendidikan. Menurut (Gusty et al., 2020) Pembelajaran secara daring merupakan solusi yang tepat guna mendukung keberhasilan social distancing dan sebagai upaya signifikan menuju keberhasilan proses belajar mengajar dalam Pandemic Covid-19 global. 
Hal yang sama juga disampaikan oleh (Simarmata et al., 2020) Melalui kegiatan pembelajaran daring menggunakan model interaktif berbasis Internet dan Learning Manajemen System (LMS) seperti menggunakan Zoom, Google Meet, Google Drive, dan sebagainya maka masalah yang dihadapi oleh para pendidik (guru dan dosen) dalam melaksanakan kegiatan pembelajaran dapat teratasi.

Menindaklanjuti keadaan darurat pada masa Pandemic Covid-19 ini, pemerintah melalui pengambilan kebijakan universitas, menginstrusikan kepada semua perguruan tinggi di Indonesia untuk melakukan proses perpindahan kegiatan perkuliahan dari konvensional ke daring dengan memanfaatkan jaringan internet, termasuk salah satu Perguruan Tinggi di Ambon yaitu Universitas Pattimura.

(Haudi et al., 2021) menyatakan bahwa masalah utama dalam melaksanakan kegiatan pembelajaran daring adalah koneksi jaringan internet, banyak terdapat mahasiswa/siswa yang tempat tinggalnya jauh dari perkotaan sulit untuk mengakses internet apalagi yang menggunakan jaringan seluler, karena masih jauh dari jangkauan sinyal seluler hal tersebut mengakibatkan ketidakstabilan jaringan bagi penggunanya. Kendala lain yaitu server error pada laptop/notebook dan keterbatasan kuota internet selama mengikuti proses pembelajaran daring. Masalah-masalah tersebut menjadi pemicu kurang optimal dan maksimalnya pelaksaan pembelajaran daring.

Program Studi PPKn sebagai salah rumpun ilmu pada FKIP Jurusan Ilmu Pengetahuan Sosial Universitas Pattimura juga tidak terlepas dari permasalahan serupa, selama proses pembelajaran daring. Berdasarkan pengamatan pada Program Studi PPKn FKIP Universitas Pattimura yang menjadi masalah pembelajaran daring selama masa Pandemic Covid-19 melalui aplikasi video conference adalah lemahnya pengawasan terhadap mahasiswa dan jaringan internet yang tidak stabil. Lemahnya pengawasan yang dimaksud adalah kurang optimalnya dosen dalam memantau mahasiswa yang fokus maupun tidak fokus selama proses pembelajaran daring karena kapasitas mahasiswa (20-50 orang) dalam mengikuti kelas daring. Dengan diterapkannya pembelajaran jarak jauh banyak mahasiswa memilih pulang ke kampung halamannya yang mengakibatkan buruknya koneksi internet di daerah tempat tinggal mereka. Kondisi ini tentu sangat mempengaruhi kualitas penerimaan materi kuliah sehingga berdampak pada sistem evaluasi pembelajaran. Menurut (Karwati, 2014) Pola pembelajaran daring maupun pembelajaran luring memiliki metodenya masing-masing dalam menerapkan pembelajaran yang berkualitas bagi mahasiswa.

Program Studi PPKn memiliki Visi yaitu Pada tahun 2025 Program studi PPKn unggul dalam menghasilkan Lulusan Yang Berkarakter Pancasila dan Profesional dalam memberdayakan masyarakat laut pulau. Visi Program Studi PPKn tersebut memiliki arti sebagai berikut: Menghasilkan Lulusan yang profesional artinya lulusan dari program studi PPKn telah profesional dalam penguasaan kompetensi pedagogik, kompetensi profesional/keahlian dalam bidang ilmu PPKn, kompetensi kepribadian dan kompetensi sosial; Berkarakter Pancasila memiliki arti yang sama dengan watak pancasila, artinya program studi dalam melaksanakan pembelajaran berorientasi pada pengembangan 
watak calon guru yang memiliki karakter sesuai dengan lima sila yang terdapat pada Pancasila.

Untuk mewujudkan Visi tersebut dosen PPKn diharapkan dapat menciptakan calon lulusan sarjana yang berpotensi menjadi pendidik professional dengan menyelenggarakan pembelajaran secara professional. Sebagai pendidik professional, dosen PPKn Universitas Pattimura ditantang untuk tetap bisa menyelanggarakan pembelajaran daring secara professional sehingga eksistensi kualitas penyaluran materi kuliah dari dosen kepada mahasiswa tidaklah berkurang dan tetap terjaga. Oleh karena itu, selain menerapkan strategi pembelajaran yang efektif seorang dosen harus merancang sasaran evaluasi pembelajaran yang efektif pula agar dapat meningkatkan partisipasi aktif dan motivasi mahasiswa dalam berkomunikasi selama proses pembelajaran daring sehingga tujuan pembelajaran yang telah ditentukan dapat tercapai dan mahasiswa sebagai penerima materi tetap terjaganya mutu belajarnya.

Merujuk kepada pendapat (Sofan Amri, 2013) Evaluasi diartikan sebagai suatu proses merencanakan, memperoleh, dan menyediakan informasi yang sangat diperlukan untuk membuat alternatif-alternatif keputusan. (Arikunto, 2012) Arti dari evaluasi sendiri dimaknai dengan dua hal, yakni pengukuran dan penilaian. Apabila lebih kepada data dalam berbentuk angka maka lazim disebut dengan pengukuran, dan apabila berkaitan dengan interpretasi data angka itu sendiri maka lazim disebut dengan penilaian.

Pengukuran merupakan kuantifikasi atau penetapan angka tentang karakteristik atau keadaan individu menurut aturan-aturan tertentu (Eko Putro Widoyoko, 2016). Sedangkan Penilaian hasil pembelajaran merupakan kegiatan menafsirkan atau memaknai data hasil pengukuran tentang kompetensi yang dimiliki oleh peserta didik setelah mengikuti proses kegiatan pembelajaran (Widyoko, 2015). Selanjutnya menurut (Prijowuntato, 2020) Dalam bidang pembelajaran, evaluasi memiliki beberapa aspek, yaitu:

a. Kegiatan evaluasi merupakan proses yang sistematis. Ini berarti bahwa evaluasi (dalam pengajaran) merupakan kegiatan terencana dan dilakukan secara berkesinambungan. Evaluasi dilakukan tidak hanya pada akhir kegiatan atau penutup pembelajaran tertentu, tetapi dilakukan pada awal pembelajaran, selama pembelajaran berlangsung, dan pada akhir pembelajaran.

b. Input, transformasi, dan output merupakan unsur-unsur penilaian bagi siswa maupun mahasiswa terkait sasaran kegiatan evaluasi.

c. Kegiatan evaluasi dan tujuan pembelajaran merupakan suatu kesatuan yang tidak dapat dipisahkan.

Melakukan evaluasi pembelajaran melalui proses pembelajaran daring (jarak jauh) terbilang cukup sulit, mengingat dosen tidak dapat mengamati dan memantau secara langsung mahasiswa mengerjakan tugas, kuis atau tes sehingga adanya kecenderungan melakukan kecurangan berupa menyontek maupun menciplak pekerjaan teman dapat terjadi selama melaksanakan kegiatan evaluasi. Akan tetapi kegiatan evaluasi tidaklah dapat dihindari atau ditinggalkan selama proses pembelajaran daring. Evaluasi harus 
tetap ada pada kegiatan pembelajaran daring, karena berfungsi sebagai pengukur dan penilai keberhasilan dari proses pembelajaran, dan pencapaian kompetensi belajar mahasiswa.

Tujuan dari peneliti melakukan penulisan ini adalah untuk menerapkan alternatif evaluasi pembelajaran daring, yang sesuai dengan kondisi yang terjadi sekarang ini, sehingga pengukuruan dan penilaian hasil pembelajaran di tengah Pandemic Covid-19 dapat berjalan dengan maksimal serta menggambarkan evaluasi pembelajaran daring yang diselenggarakan oleh dosen Prodi PPKn FKIP Universitas Pattimura. Persoalannya yaitu usaha-usaha apa saja yang harus dilakukan oleh dosen PPKn sebagai upaya dalam menerapkan dan menjalankan evaluasi pembelajaran selama proses pembelajaran daring? Dan apakah evaluasi pembelajaran tersebut berpengaruh, baik terhadap keterlibatan mahasiswa dalam aktifitas pembelajarannya maupun pencapaian tujuan pembelajarannya. Melalui artikel ini, penulis akan mengemukakan solusi terkait kondisi atau permasalahan yang terjadi pada sistem evaluasi pembelajaran di tengah Pandemic Covid-19.

Adapun terdapat beberapa hasil penelitian terdahulu yang relevan dengan penelitian yang dilakukan oleh peneliti sekarang ini, yaitu sebagai berikut:

a. Hasil Penelitian (Riyanda et al., 2020) yang berjudul "Evaluasi Implementasi Sistem Pembelajaran Daring Fakultas Keguruan Dan Ilmu Pendidikan Universitas Lampung". Pada penelitian ini terdapat empat komponen pelaksanaan program sistem pembelajaran daring yang ditinjau berdasarkan model CIPP yaitu component context, input, process, dan product. Component context dalam penelitian evaluasi ini memiliki tiga indikator. Pertama, indikator tujuan program diperoleh TPR $86,40 \%$ yang masuk kategori baik. Kedua, indikator kebutuhan diperoleh nilai TPR sebesar 79,57\% dengan kategori baik. Ketiga, indikator lingkungan diperoleh nilai TPR sebesar $82,75 \%$ dengan kategori baik. Dari indikator diatas dapat dilihat bahwa pelaksanaan sistem pembelajaran daring dilingkungan FPMIPA tergolong baik.

b. Hasil Penelitian (Astuti, 2020) yang berjudul "Potret Evaluasi Pembelajaran Daring (E-Learning) Mahasiswa Kesehatan Dimasa Pandemi Covid-19”. Hasil penelitian dikumpulkan menggunakan kuisioner yang dibagikan melalui whatsapp group menunjukkan bahwa selama pembelajaran daring 42,65\% responden berada di kost/rumah di pulau Jawa, 95,59\% responden mampu mengoperasikan sarana belajar secara mandiri, 47,05\% responden menggunakan sarana handphone dan laptop pribadi, $80,88 \%$ responden menggunakan kuota internet, $94,12 \%$ belum pernah mendapatkan bantuan kuota internet, $76,47 \%$ responden mengalami kendala saat pembelajaran daring, 47,05\% menggunakan aplikasi google classroom, $69,12 \%$ responden menilai pembelajaran daring sesuai RPS, 39,71\% responden menilai jadwal perkuliahan kurang sesuai dengan jadwal kuliah, 58,82\% responden cukup paham dengan materi yang disampaikan. 
Berbeda dengan kedua penelitian diatas yang mengutamakan sistem pembelajaran daring dan pelaksaan kuliah daring, pada penelitian ini peneliti lebih merujuk pada sistem evaluasi pembelajaran daring untuk meningkatkan kualitas pelaksanaan pembelajaran daring selama Pandemic Covid-19 sehingga dapat membantu mahasiswa menjaga mutu belajar dan mencapai kompetensi pembelajarannya.

\section{Metode Penelitian}

Penelitian ini menggunakan metode kualitatif yang dipaparkan secara deskriptif. pmenggambarkan langkah-langkah peneliti dalam melakukan penelitian untuk mengumpulkan sumber informasi terkait evaluasi pembelajaran daring yang diterapkan dosen FKIP Prodi PPKn Universitas Pattimura.

Merujuk kepada pendapat (Sugiyono, 2013) Penelitian kualitatif merupakan metode penelitian naturalistic karena penelitiannya dilakukan pada kondisi yang alamiah (natural setting), dan data yang terkumpul dianalisis secara kualitatif. Sedangkan menurut (Rukin, 2019). Penelitian kualitatif adalah riset yang bersifat deskriptif dan cenderung menggunakan analisis dengan pendekatan induktif. Penonjolan proses penelitian dilakukan agar fokus penelitian sesuai dengan fakta di lapangan.

Penelitian kualitatif bersifat deskrptif, karena mendiskripsikan suatu obyek, fenomena, atau setting social yang akan dituangkan dalam dalam tulisan yang bersifat naratif. Arti dalam penulisannya data dan fakta yang dihimpun berbentuk kata atau gambar daripada angka. Dalam penulisan laporan penelitian kualitatif berisi kutipankutipan data (fakta) yang diungkap di lapangan untuk memberikan dukungan terhadap apa yang disajikan dalam laporannya (Anggito \& Setiawan, 2018).

Dalam penelitian ini digunakan teknik observasi terlibat langsung. Peneliti akan melakukan review terhadap berbagai dokumen atau foto-foto (Rukin, 2019). Pada penelitian ini penulis melakukan observasi terhadap komponen-komponen yang mendukung evaluasi strategi pembelajaran seperti materi kuliah, proses perkuliahan, daftar dosen pengampu, daftar mahasiswa dan lain sebagainya.

\section{Hasil dan Pembahasan}

Pada bagian ini akan diuraikan tentang hasil dan pembahasan mengenai sistem proses pembelajaran daring yang dilakukan dalam menerapkan strategi evaluasi pembelajaran daring. Sistem proses pembelajaran daring yang telah dilaksanakan adalah sebagai berikut:

1. Perencanaan Pembelajaran Daring

a. Pelaksanaan perkuliahan sesuai dengan Kurikulum Program Studi PPKn

b. Menyiapkan RPS dan Bahan Ajar

c. Menyiapkan media pembelajaran daring (aplikasi video conference, aplikasi platform, layanan web, dan lain sebagainya)

d. Memastikan ketersediaan RPS, Bahan Ajar dan Media Pembelajaran Daring

2. Pelaksanaan Pembelajaran Daring

a. Melakukan kontrak perkuliahan dengan mahasiswa 
b. Proses Pembelajaran selama 1 semester (16 x pertemuan)

c. Pengambilan presensi/kehadiran melalui aplikasi web Google Forms

d. Dosen melakukan evaluasi pembelajaran daring melalui jurnal pembelajaran, studi kasus, artikel review film dan simulasi mengajar

e. Dokumentasi aktivitas proses pembelajaran daring

3. Umpan Balik (feedback)

a. Hasil evaluasi pembelajaran daring di analisa sesuai dengan temuan dari hasil pengerjaan oleh mahasiswa PPKn

b. Hasil analisis digunakan sebagai bahan untuk umpan balik perbaikan proses pembelajaran untuk semester berikutnya

Berbagai strategi evaluasi pembelajaran daring yang telah diterapkan oleh dosen PPKn melalui proses pembelajaran daring adalah sebagai berikut:

a. Jurnal Pembelajaran, sistem evaluasi yang dilakukan untuk menilai tingkat pemahaman mahasiswa terkait materi yang diberikan selama pembelajaran daring,

b. Studi Kasus, sistem evaluasi yang diberikan untuk mengasah kemampuan berpikir kritis mahasiswa dalam menyampaikan pendapat selama proses pembelajaran daring,

c. Artikel Review Film, sistem evaluasi yang diberikan untuk mengasah kemampuan berpikir kritis mahasiswa melalui tulisan terkait materi yang diberikan selama pembelajaran daring,

d. Simulasi Mengajar, sistem evaluasi yang diterapkan pada akhir pembelajaran untuk mengasah ketrampilan mengajar dan kerjasama mahasiswa.

Tabel 1

Penerapan Evaluasi Pembelajaran dan Keterlibatan Mahasiswa

\begin{tabular}{|c|c|c|}
\hline No. & Penerapan Evaluasi Pembelajaran & Keterlibatan Mahasiswa \\
\hline 1. & Jurnal Pembelajaran & $\begin{array}{l}\text { a. memahami materi/bahan ajar } \\
\text { b. melakukan tanya jawab } \\
\text { c. mengambil pokok-pokok pikiran } \\
\text { d. menuangkan gagasan individual }\end{array}$ \\
\hline 2. & Studi Kasus & $\begin{array}{l}\text { a. menganalisis masalah yang terjadi } \\
\text { b. mengungkapkan gagasan pemecahan masalah } \\
\text { c. mengajukan pendapat dampak solusi } \\
\text { pemecahan masalah } \\
\text { d. membuat kesimpulan }\end{array}$ \\
\hline 3. & Artikel Review Film & $\begin{array}{l}\text { a. memahami alur cerita } \\
\text { b. membuat ulasan secara individual } \\
\text { c. memberikan gambaran terkait objek yang } \\
\text { direview } \\
\text { d. mengemukakan pendapat/pemikiran }\end{array}$ \\
\hline 4. & Simulasi Mengajar & $\begin{array}{l}\text { a. membuat rencana pembelajaran } \\
\text { b. menyiapkan materi/bahan ajar } \\
\text { c. menggunakan berbagai media dan sumber } \\
\text { belajar } \\
\text { d. melakukan kerjasama secara kooperatif } \\
\text { e. mendemonstrasikan } \\
\text { f. melakukan tanya-jawab } \\
\text { g. memberikan feedback }\end{array}$ \\
\hline
\end{tabular}


Berdasarkan pemaparan pada tabel di atas, maka dapat dilihat bahwa dosen Prodi PPKn telah mengupayakan berbagai strategi evaluasi yang dilakukan selama proses pembelajaran daring selain melaksanakan tes atau kuis seperti evaluasi pembelajaran pada umumnya sebelum perkuliahan secara online diterapkan. Walaupun proses pembelajaran dilakukan secara virtual tetapi evaluasi pembelajaran tetap bisa dilaksanakan dengan baik sehingga tidak mengurangi kualitas dari pencapaian hasil belajar mahasiswa.

Kunci keberhasilan dari evaluasi pembelajaran daring karena adanya keterlibatan aktif mahasiswa sebagai subjek belajar dalam proses pembelajaran. Subjek belajar yang dimaksud adalah tingkat pencapaian tujuan pembelajaran mahasiswa tidak dinilai hanya dengan angka tetapi melalui evaluasi pembelajaran mahasiswa bisa mengembangkan potensinya secara langsung melalui proses pembelajaran daring.

Ketika mahasiswa mengerjakan jurnal pembelajaran sebagaimana yang telah diterapkan oleh dosen PPKn tersebut di atas, dapat dilihat bahwa mahasiswa berusaha untuk memahami materi/bahan ajar yang disampaikan oleh dosen, apabila terdapat materi yang tidak dipahami maka mahasiswa akan bertanya secara langsung dan jika ada temannya yang bisa menjawab maka dosen akan mengijinkan mahasiswa yang bersangkutan untuk menjelaskan. Tanya jawab tersebut menimbulkan interaksi aktif antar dosen dan mahasiswa selama proses pembelajaran daring. Mahasiswa yang memahami dengan baik materi/bahan ajar yang telah dipaparkan, dapat mengambil pokok-pokok pikiran dari materi/bahan ajar dan menuangkan gagasannya dalam jurnal pembelajaran, namun ada juga mahasiswa yang belum memahami tetapi malu atau malas bertanya sehingga pengerjaan jurnal pembelajarannya tidak terstruktur sesuai dengan arahan dari dosen.

Dalam strategi evaluasi pembelajaran studi kasus, mahasiswa berpartisipasi aktif dalam menganalisis masalah yang terjadi, mengungkapkan gagasan pemecahan masalah, mengajukan pendapat dampak solusi pemecahan masalah, dan membuat kesimpulan. Evaluasi pembelajaran studi kasus melibatkan keaktifan mahasiswa secara individu, agar mahasiswa dapat menuangkan pemikirannya melalui tulisan secara kritis terkait isu/masalah yang dihadapi masyarakat masa kini.

Evaluasi pembelajaran artikel review film dilaksanakan untuk mengembangkan kemampuan menulis mahasiswa dalam mengulas sebuah cerita menjadi sederhana dengan memperhatikan hal-hal menarik yang akan dimunculkan dalam review namun tidak terlepas dari materi/bahan ajar yang diberikan. Keterlibatan mahasiswa dalam membuat artikel review film yaitu memahami alur cerita, membuat ulasan secara individual, memberikan gambaran terkait objek yang direview, dan mengemukakan pendapat/pemikiran. Meskipun masih terdapat mahasiswa yang belum mampu menulis artikel review film dengan baik, akan tetapi dengan diterapkannya strategi evaluasi pembelajaran artikel review film dapat membantu melatih kreatifitas mahasiswa dalam menulis.

Partisipasi mahasiswa dalam simulasi mengajar yaitu membuat rencana pembelajaran, menyiapkan materi/bahan ajar, menggunakan berbagai media dan sumber 
belajar, melakukan kerjasama secara kooperatif, mendemonstrasikan, melakukan tanyajawab, dan memberikan feedback. Simulasi mengajar diterapkan dengan cara membagi kelompok, pada kelompok tersebut akan dibagi peran, siapa yang menjadi pendidik (guru) dan siapa yang menjadi peserta didik (siswa). Mahasiswa yang berperan menjadi guru akan melaksanakan pembelajaran kepada teman-temannya yang berperan sebagai murid dengan berlatar belakang kondisi belajar di dalam kelas melalui aplikasi video conference. Namun, sebelum melaksanakan simulasi mengajar secara daring, setiap kelompok membuat/menyusun hal-hal yang terkait dengan kegiatan tersebut, sehingga adanya kerjasama yang baik dan interaksi yang aktif dalam kelompok pada saat mendemonstrasikan simulasi mengajar.

Sesuai dengan hasil pembahasan di atas menurut (Junaedi et al., 2018) Tujuan evaluasi pembelajaran secara umum adalah untuk mengetahui keefektifan dan efisiensi sistem pembelajaran secara luas. Selain itu, evaluasi pembelajaran juga ditujukan untuk menilai efektivitas strategi pembelajaran, menilai dan meningkatkan efektivitas program kurikulum, menilai dan meningkatkan efektivitas pembelajaran, membantu belajar peserta didik, mengidentifikasi kekuatan dan kelemahan peserta didik, serta untuk menyediakan data yang membantu dalam membuat keputusan.

Sedangkan fungsi evaluasi pembelajaran adalah untuk mengetahui progress belajar peserta didik, apakah selama proses pembelajaran berlangsung peserta didik mampu memahami setiap materi yang dijelaskan sehingga pencapaian belajar peserta didik dapat terlaksana dengan baik (Miterianifa \& Mas'ud Zein., 2016).

Berdasarkan uraian tentang pengaruh upaya dosen dalam menerapkan evaluasi pembelajaran daring terhadap keterlibatan mahasiswa diatas, maka dapat dikemukakan bahwa penerapan evaluasi pembelajaran daring telah mewujudkan pencapaian maksimal tujuan pembelajaran mahasiswa. Keterlibatan mahasiswa secara aktif dalam proses evaluasi pembelajaran daring berpengaruh positif pada kemajuan belajar. Mahasiswa diarahkan untuk belajar memahami materi/bahan ajar secara mandiri melalui jurnal pembelajaran; menganalisis masalah-masalah yang terjadi di lingkungan masyarakat dalam kajian studi kasus; melatih kemampuan menulis mahasiswa dalam mengulas sebuah karya berbentuk film menjadi sebuah artikel review yang menarik minat pembaca; serta mengasah kemampuan mahasiswa untuk berbicara, menyiapkan materi/bahan ajar, menyusun rencana pembelajaran, dan cara bekerjsama dalam berinteraksi melalui simulasi mengajar. Keadaan seperti ini membawa dampak positif dalam proses pembelajaran daring, karena melalui strategi evaluasi pembelajaran yang diterapkan, maka dapat tercapainya kualitas dari pencapaian hasil belajar mahasiswa.

\section{Kesimpulan}

Melalui hasil penelitian yang telah dilaksanakan maka dapat ditarik kesimpulan yaitu pelaksanaan evaluasi pembelajaran daring yang beriorientasi pada pencapaian hasil tujuan pembelajaran mahasiswa adalah sebagai berikut : Pertama, sistem proses pembelajaran daring dengan menggunakan indikator yang dapat diterapkan pada lingkungan program studi PPKn, melalui cara tersebut setidak-tidaknya akan 
memberikan gambaran yang jelas kepada program studi berkaitan dengan pelaksaan pembelajaran daring dan pencapaian evaluasi pembelajaran mahasiswa. Kedua, penerapan strategi evaluasi pembelajaran daring oleh dosen PPKn yang meliputi: a) jurnal pembelajaran, b) studi kasus. c) artikel review film, dan d) simulasi mengajar.

Dengan adanya upaya dosen PPKn dalam melaksanakan evaluasi pembelajaran daring telah berhasil menciptakan kondisi belajar yang mampu meningkatkan keaktifan mahasiswa selama proses pembelajaran daring, sehingga tujuan pembelajaran dapat tercapai. Strategi evaluasi pembelajaran secara daring memberikan pemahaman kepada mahasiswa bahwa penilaian keberhasilan mahasiswa dalam mencapai tujuan pembelajaran tidak hanya diukur dengan angka, tetapi mengenai sejauh mana mahasiswa dapat memahami setiap materi yang diberikan dan mengembangkan potensi dirinya melalui proses evaluasi pembelajaran yang diterapkan. 


\section{BIBLIOGRAFI}

Anggito, A., \& Setiawan, J. (2018). Metodologi penelitian kualitatif. CV Jejak (Jejak Publisher).

Arikunto, S. (2012). Dasar-dasar evaluasi pendidikan edisi 2. Jakarta: Bumi Aksara.

Astuti, L. D. (2020). The Potret Evaluasi Pembelajaran Daring (E-Learning) Mahasiswa Kesehatan Dimasa Pandemi Covid-19. Jurnal Kebidanan, 9(2), 25-33.

Eko Putro Widoyoko, S. (2016). Penilaian hasil pembelajaran di sekolah. Yogyakarta: Pustaka Pelajar.

Gusty, S., Nurmiati, N., Muliana, M., Sulaiman, O. K., Ginantra, N. L. W. S. R., Manuhutu, M. A., Sudarso, A., Leuwol, N. V., Apriza, A., \& Sahabuddin, A. A. (2020). Belajar Mandiri: Pembelajaran Daring di Tengah Pandemi Covid-19. Yayasan Kita Menulis.

Haudi, S. P., Hadion Wijoyo, S. E., \& SH, S. (2021). Pengantar Ilmu Pemerintahan. Insan Cendekia Mandiri.

Junaedi, F., Nugroho, H., \& Wahyono, S. B. (2018). Pembelaan Pada Persebaya dan Glorifikasi Bonek dalam Pemberitaan Jawa Pos tentang Konflik Persebaya dan PSSI. Komuniti: Jurnal Komunikasi Dan Teknologi Informasi, 10(1), 54-67.

Miterianifa \& Mas'ud Zein. (2016). Evaluasi Pembelajaran Kimia: Model Integrasi Sains Dengan Islam. Cahaya Firdaus Publishing and Printing.

Mudyahardjo Redja. (2013). Pengantar Pendidikan. PT Raja Grafindo Persada.

PAUD Kemdikbud. (2020). Website Internal. anggun.paud.kemdikbud.go.id/

Prijowuntato, S. W. (2020). Evaluasi pembelajaran. Sanata Dharma University Press.

Riyanda, A. R., Herlina, K., \& Wicaksono, B. A. (2020). Evaluasi Implementasi Sistem Pembelajaran Daring Fakultas Keguruan Dan Ilmu Pendidikan Universitas Lampung. IKRA-ITH HUMANIORA: Jurnal Sosial Dan Humaniora, 4(1), 66-71.

Rukin, S. P. (2019). Metodologi Penelitian Kualitatif. Yayasan Ahmar Cendekia Indonesia.

Simarmata, J., Simanihuruk, L., Ramadhani, R., Safitri, M., Wahyuni, D., \& Iskandar, A. (2020). Pembelajaran STEM Berbasis HOTS dan Penerapannya. Yayasan Kita Menulis.

Sofan Amri. (2013). Pengembangan dan Model Pembelajaran dalam Kurikulum 2013. Prestasi Pustakaraya. 
Marlyen Sharly Sapulette

Sugiyono, P. D. (2013). Metode penelitian manajemen. Bandung: Alfabeta, CV.

Widyoko, E. P. E. P. (2015). Pembelajaran. Pustaka Pelajar. 